\title{
Cytochrome P450 1A1
}

National Cancer Institute

\section{Source}

National Cancer Institute. Cytochrome P450 1A1. NCI Thesaurus. Code C17296.

Cytochrome P450 1A1 (512 aa, 58 kDa) is encoded by the human CYP1A1 gene. This protein is involved in the metabolism of fatty acids and xenobiotics. 